\title{
Hyperoncotic colloids and acute kidney injury: a meta-analysis of randomized trials
}

\author{
Christian J Wiedermann ${ }^{1 *}$, Stefan Dunzendorfer ${ }^{2}$, Luigi U Gaioni ${ }^{1}$, Francesco Zaraca ${ }^{3}$, Michael Joannidis ${ }^{2}$
}

\begin{abstract}
Introduction: It has been hypothesized that hyperoncotic colloids might contribute to acute kidney injury (AKI). However, the validity of this hypothesis remains unclear.

Methods: A meta-analysis was conducted of randomized controlled trials evaluating AKI after infusion of hyperoncotic albumin and hydroxyethyl starch (HES) solutions. Mortality was a secondary endpoint. Eligible trials were sought by multiple methods, and the pooled odds ratios (OR) for AKI and death and $95 \%$ confidence intervals $(\mathrm{Cl})$ were computed under a random effects model.

Results: Eleven randomized trials with a total of 1220 patients were included: 7 evaluating hyperoncotic albumin and 4 hyperoncotic HES. Clinical indications were ascites, surgery, sepsis and spontaneous bacterial peritonitis. Hyperoncotic albumin decreased the odds of AKI by $76 \%(\mathrm{OR}, 0.24 ; \mathrm{Cl}, 0.12-0.48 ; P<0.0001)$, while hyperoncotic HES increased those odds by $92 \%(\mathrm{OR}, 1.92 ; \mathrm{Cl}, 1.31-2.81 ; P=0.0008)$. Parallel effects on mortality were observed, with hyperoncotic albumin reducing the odds of death by $48 \%(\mathrm{OR}, 0.52 ; \mathrm{Cl}, 0.28-0.95 ; P=0.035)$ and hyperoncotic HES raising those odds by $41 \%(\mathrm{OR}, 1.41 ; \mathrm{Cl}, 1.01-1.96 ; P=0.043)$.

Conclusions: This meta-analysis does not support the hypothesis that hyperoncotic colloid solutions per se injure the kidney. Renal effects appear instead to be colloid-specific, with albumin displaying renoprotection and HES showing nephrotoxicity.
\end{abstract}

\section{Introduction}

The potential for beneficial or deleterious renal effects is a key consideration in the selection and use of colloid solutions for clinical fluid management. In a systematic review, albumin was found to protect the kidney, whereas the carbohydrate-based artificial colloids hydroxyethyl starch (HES) and dextran were frequently associated with acute kidney injury (AKI) [1]. Confirmation with respect to the negative effects of HES has been provided by two recent meta-analyses of randomized trials showing increased incidence of acute renal failure (ARF) [2] and need for renal replacement therapy (RRT) [3] in patients receiving HES and by a systematic review [4].

Renal effects might be influenced not only by the specific properties of the particular colloid molecule but also by higher colloid osmotic pressure (COP) [5],

\footnotetext{
* Correspondence: christian.wiedermann@asbz.it

'Department of Internal Medicine, Central Hospital of Bolzano, Lorenz Böhler Street 5, 39100 Bolzano, Italy

Full list of author information is available at the end of the article
}

assuming that increased COP decreases effective glomerular filtration pressure and thus glomerular filtration rate antagonizing hydrostatic pressure [6]. Colloid solutions can be classified as hypo-oncotic, iso-oncotic, or hyperoncotic according to whether their COP is less than, similar to, or greater than that of plasma, respectively. COP is strongly dependent upon the concentration of colloid in the solution [7]. Thus, $4 \%$ to $5 \%$ albumin is hypo-oncotic, whereas $20 \%$ to $25 \%$ albumin is hyperoncotic [8-11]. Similarly, 6\% HES is iso-oncotic, whereas $10 \%$ HES is hyperoncotic $[8,9,11,12]$. Molecular weight and substitution show little if any effect on the COP of HES solutions [9,11].

With their capacity to draw interstitial fluid into the intravascular compartment, hyperoncotic solutions provide an attractive option for volume expansion because they are rapidly effective in a small infused volume and can serve to minimize edema [13]. However, in an analysis of data from the CRYstalloids or COlloids (CRYCO) study observational study of 1,013 intensive care unit patients, exposure to hyperoncotic solutions of

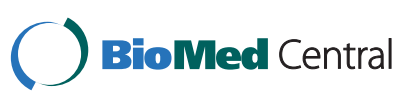


either albumin or HES was associated with increased occurrence of AKI as compared with crystalloids or hypo-oncotic colloids [5]. That analysis suggests that hyperoncotic colloids per se might be harmful to the kidney. On the other hand, no adverse renal effects were evident in a multicenter study of 600 patients receiving hyperoncotic $25 \%$ albumin [14] or in a recent meta-analysis of 25 randomized trials (with a total of 1,485 patients) evaluating hyperoncotic albumin [13]. Moreover, in randomized trials, iso-oncotic 6\% HES increased the incidence of ARF in patients with severe sepsis or septic shock [15] and the need for RRT after kidney transplantation [16]. In light of the conflicting data, investigators are uncertain about the renal effects of hyperoncotic colloids. The present meta-analysis of randomized trials was designed to test the hypothesis that hyperoncotic colloids per se increase the incidence of AKI.

\section{Materials and methods Endpoints}

This meta-analysis addressed the question: does infusion of hyperoncotic $20 \%$ to $25 \%$ albumin or $10 \%$ HES to prevent or correct hypovolemia increase the risk of AKI as compared with crystalloid, hypo-oncotic $4 \%$ to $5 \%$ albumin, or no fluid? Mortality was a secondary endpoint.

\section{Study selection}

Parallel-group randomized controlled trials (RCTs) were eligible for inclusion if they evaluated the occurrence of AKI in patients receiving hyperoncotic solutions of $20 \%$ to $25 \%$ albumin or $10 \%$ HES for prevention or correction of hypovolemia. The control regimen could consist of crystalloid, hypo-oncotic $4 \%$ to $5 \%$ albumin, or no fluid but not a non-fluid intervention such as active drug or a procedure. Hypo-oncotic colloids were also included as control fluids in the CRYCO study [5]. Trials employing an iso-oncotic 6\% HES control arm or comparing two hyperoncotic colloids were excluded. The difference in colloid osmotic pressure (COP) between hyperoncotic colloids and iso-oncotic 6\% HES of 12 to $18 \mathrm{~mm} \mathrm{Hg}$ is smaller than that between hyperoncotic colloids and hypo-oncotic $4 \%$ to $5 \%$ albumin $[8,9]$; as a consequence of the smaller difference, AKI and mortality comparisons versus iso-oncotic 6\% HES as a control fluid would likely be relatively insensitive. Colloids were classified as hyperoncotic on the basis of final concentration at the time of use; hence, cardiac surgery trials of extracorporeal circuit priming in which hyperoncotic colloid was extensively diluted prior to use were not eligible. No restrictions were placed on trial time period or reporting language. Both published and unpublished trials were sought.

\section{Search strategy}

Computer searches were performed between April and July 2010 in Medline, Embase, records of published and unpublished trials in the Cochrane Library, the ClinicalTrials.gov website, and the abstract databases from major meetings in surgery, anesthesiology, intensive care, and hepatology. The search terms of inclusion were the following: kidney, renal, renin, mortality, injury, failure, complication, adverse, illness, outcome, cirrhosis, albumin, hetastarch, pentastarch, pentaspan, hyperoncotic, 10\%, $20 \%$, 25\%, clinical trials, prospective studies, fluid therapy, random allocation, and humans. The search terms of exclusion were cohort study, observational, survey, pharmacokinetic, retrospective studies, RCTs as topic, practice guidelines as topic, animal, rats, pigs, swine, review, news, letter, comment, editorial, meta-analysis, hypervolemia, molecular adsorbent recirculating system [MARS], MARS, albumin-bound, chemotherapy, paclitaxel, methotrexate, nanoparticle, and microsphere. Roots and variants of the search terms were also used. Eligible trials were also sought by examining the reference lists of primary study publications and review articles and contacting resuscitation fluid suppliers. All investigators participated in determining the eligibility of candidate trials. Differences in interpretation were resolved through discussion.

\section{Data extraction}

The authors, time periods, patients, and methods of each trial report were scrutinized to avoid duplication and ensure the most complete possible data set. From the reports of the included studies, the following data were extracted: year reported, number of patients, clinical indication, blinding, allocation concealment, patient age and gender, fluid regimen, criteria for diagnosing AKI, and incidence of AKI and death on the basis of intent to treat.

\section{Statistical analysis}

The pooled odds ratios (ORs) for AKI and mortality and their 95\% confidence intervals (CIs) were computed under a random effects model. Heterogeneity was evaluated by Cochran $\mathrm{Q}$ test and calculation of the $\mathrm{I}^{2}$ statistic and publication bias by linear regression of standardized effect in relation to precision. Study quality was judged on the basis of blinding and allocation concealment. Analysis was performed with Comprehensive Meta Analysis version 2.2.048 (Biostat, Inc., Englewood, NJ, USA) statistical software.

\section{Results}

\section{Included trials}

The number of candidate RCTs identified and screened was 109 (Figure 1). Upon detailed evaluation of the candidates, 98 were excluded. The most common reasons 


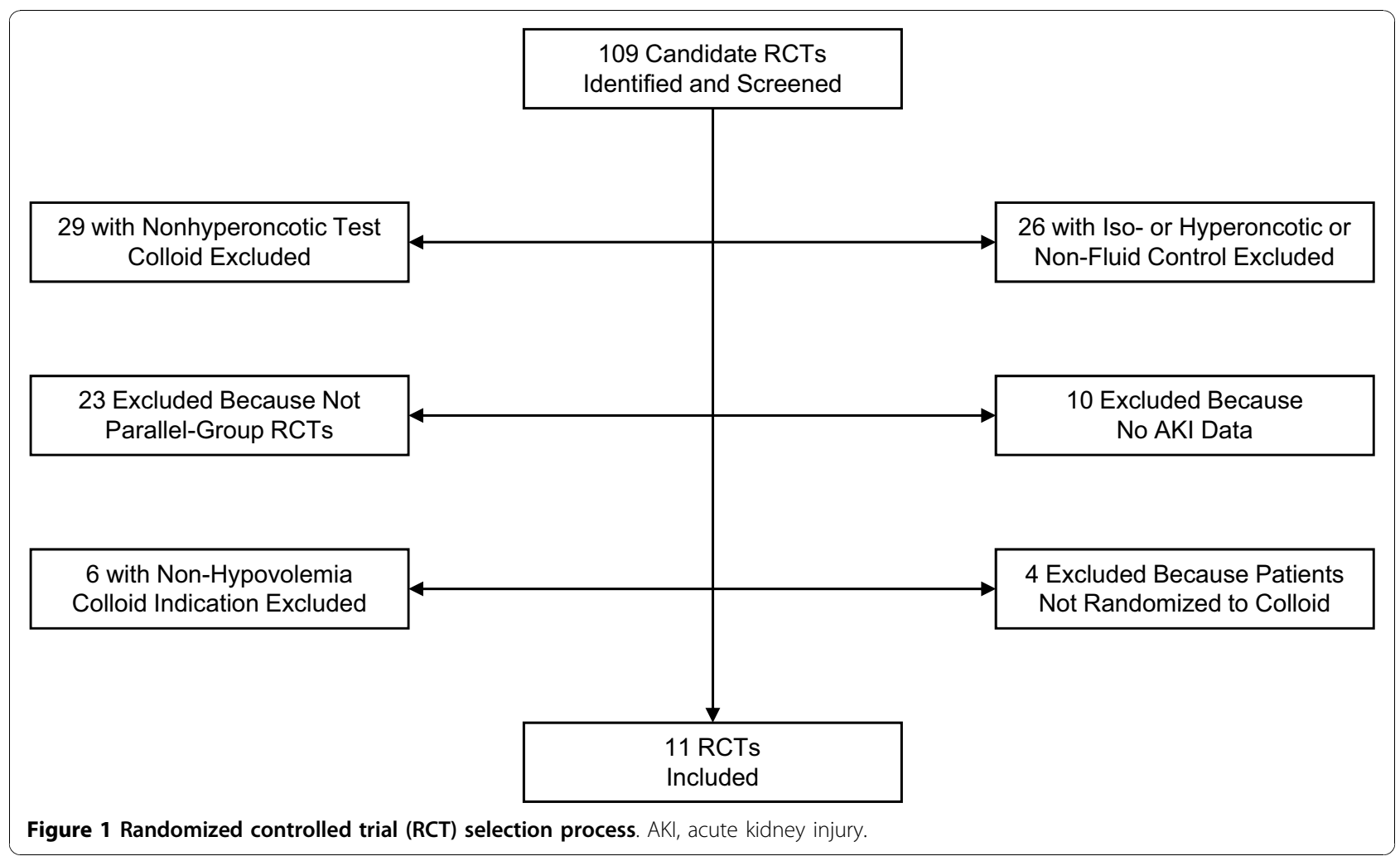

for exclusion were a non-hyperoncotic test colloid, an iso- or hyperoncotic colloid, a drug or procedure control, and an investigational design other than a parallelgroup RCT. Eleven RCTs with a total of 1,220 patients fulfilled all eligibility criteria and were included in the meta-analysis [17-27]. All trials had been published. Three of the 11 included trials were reported in the $1980 \mathrm{~s}$ and four each in the $1990 \mathrm{~s}$ and $2000 \mathrm{~s}$ (Table 1). Two trials were blinded and two were not, whereas the use of blinding was unspecified for the remaining seven trials. Allocation concealment was adequate in five trials and unspecified in six. The indication for volume expansion with colloid was treatment of ascites as an adjunct to paracentesis in three trials and to diuretics in one, surgery in three, and sepsis and spontaneous bacterial peritonitis in two each. One trial encompassed separate protocols for acute treatment of ascites in the hospital and subsequent long-term outpatient maintenance therapy [22]. Only the results from the acute treatment protocol were used in the meta-analysis. The median number of patients per trial was 72 , and the interquartile range (IQR) was 32 to 116 . More than 100 patients were evaluated in four trials, but only one trial involved over 200 patients. With 537 patients, that trial [25] was by far the largest included in the meta-analysis. Mean ages of patients in the trials were comparatively homogeneous. Whereas age averaged 49.1 years in one trial, the mean values in the other 10 trials fell within the relatively narrow range of 55.7 to 64.7 years. The median percentage of male patients in the included trials was $60 \%$ (IQR $60 \%$ to $65 \%$ ). Seven trials evaluated hyperoncotic $20 \%$ to $25 \%$ albumin, and four trials evaluated hyperoncotic $10 \%$ HES. Control treatments were no colloid in seven trials, crystalloid in three, and hypooncotic colloid in one.

\section{Acute kidney injury}

The AKI diagnosis criteria adopted in four trials included an increase of $50 \%$ or more in serum creatinine or blood urea nitrogen (Table 1). The need for RRT was the criterion in three trials, whereas other or unspecified criteria were applied in two trials each. Across all 11 studies, 199 of 1,220 patients (16\%) developed AKI (Figure 2). As shown in Figure 2, hyperoncotic albumin decreased the odds of AKI by $76 \%$ (OR 0.24 , CI 0.12 to $0.48 ; P<0.0001)$. Among the seven trials evaluating hyperoncotic albumin, there was no evidence of either heterogeneity $\left(P=0.81 ; \mathrm{I}^{2}=0 \%\right)$ or publication $(P=$ 0.74 ) bias with respect to the AKI endpoint. Hyperoncotic HES showed the opposite effect (Figure 2), increasing the odds of AKI by $92 \%$ (OR 1.92, CI 1.31 to $2.81 ; P=$ $0.0008)$. Neither heterogeneity $\left(P=0.89 ; \mathrm{I}^{2}=0 \%\right)$ nor publication $(P=0.55)$ bias was detectable in the AKI data from the four trials of hyperoncotic HES. 
Table 1 Included randomized trials

\begin{tabular}{|c|c|c|c|c|}
\hline Trial & Indication & $\begin{array}{l}\text { Mean } \\
\text { age, } \\
\text { years }\end{array}$ & Treatment & AKI criteria \\
\hline $\begin{array}{l}\text { Zetterström } \\
\text { and } \\
\text { Hedstrand } \\
{[17], 1981}\end{array}$ & Elective major abdominal surgery & 58.5 & $\begin{array}{l}\text { Postoperative crystalloid with } \\
\text { versus without } 20 \% \text { albumin }\end{array}$ & At least $70 \% \mathrm{SCr}$ and urea increase \\
\hline $\begin{array}{l}\text { Ginès et al. } \\
\text { [18], } 1988\end{array}$ & $\begin{array}{l}\text { Treatment of ascites in } \\
\text { hospitalized cirrhotic patients }\end{array}$ & 57.0 & $\begin{array}{l}\text { Paracentesis with versus without } \\
20 \% \text { albumin }\end{array}$ & $\begin{array}{l}\text { At least } 50 \% \mathrm{SCr} \text { or BUN increase to greater than } \\
1.5 \text { or } 30 \mathrm{mg} / \mathrm{dL} \text {, respectively }\end{array}$ \\
\hline $\begin{array}{l}\text { London et al. } \\
{[19], 1989}\end{array}$ & CPB surgery & 63.5 & $\begin{array}{l}10 \% \text { pentastarch versus } 5 \% \\
\text { albumin for first } 24 \text { hours } \\
\text { postoperatively }\end{array}$ & $\begin{array}{l}\text { Emergency dialysis necessitated by acute renal } \\
\text { failure }\end{array}$ \\
\hline $\begin{array}{l}\text { García- } \\
\text { Compeán et } \\
\text { al. [20], } 1993\end{array}$ & $\begin{array}{l}\text { Hospital treatment of tense ascites } \\
\text { causing respiratory dysfunction in } \\
\text { cirrhotic patients }\end{array}$ & 55.7 & $\begin{array}{l}\text { Total therapeutic paracentesis with } \\
\text { versus without } 25 \% \text { albumin }\end{array}$ & $\begin{array}{l}\text { Greater than } 50 \% \mathrm{SCr} \text { or BUN increase to greater } \\
\text { than } 1.5 \mathrm{mg} / \mathrm{dL} \text { or greater than } 30 \mathrm{mg} / \mathrm{dL} \text {, } \\
\text { respectively }\end{array}$ \\
\hline $\begin{array}{l}\text { Dehne et al. } \\
\text { [21], } 1997\end{array}$ & $\begin{array}{l}\text { Hypovolemia in surgical ICU } \\
\text { patients }\end{array}$ & 49.1 & $\begin{array}{l}\text { Normocaloric parenteral nutrition } \\
\text { with versus without } 12 \mathrm{~mL} / \mathrm{kg} \text { per } \\
\text { day HES 200/0.5 }\end{array}$ & Acute renal failure \\
\hline $\begin{array}{l}\text { Gentilini et } \\
\text { al. [22], } 1999\end{array}$ & $\begin{array}{l}\text { Hospital treatment of ascites in } \\
\text { cirrhotic patients unresponsive to } \\
\text { bed rest and low-sodium diet }\end{array}$ & 62.1 & $\begin{array}{l}\text { Diuretics with versus without } 50 \\
\mathrm{~mL} 25 \% \text { albumin daily }\end{array}$ & Acute renal failure \\
\hline $\begin{array}{l}\text { Sort et al. } \\
{[23], 1999}\end{array}$ & Spontaneous bacterial peritonitis & 61.0 & $\begin{array}{l}\text { Intravenous cefotaxime with versus } \\
\text { without } 1.5 \mathrm{~g} / \mathrm{kg} 20 \% \text { albumin on } \\
\text { day } 1 \text { plus } 1.0 \mathrm{~g} / \mathrm{kg} \text { on day } 3\end{array}$ & $\begin{array}{l}\text { Greater than } 50 \% \mathrm{SCr} \text { or BUN increase and, in } \\
\text { patients without pre-existing renal failure, greater } \\
\text { than } 1.5 \mathrm{mg} / \mathrm{dL} \text { SCr or greater than } 30 \mathrm{mg} / \mathrm{dL} \text { BUN }\end{array}$ \\
\hline $\begin{array}{l}\text { Sola-Vera et } \\
\text { al. [24], } 2003\end{array}$ & $\begin{array}{l}\text { Prevention of paracentesis- } \\
\text { induced circulatory dysfunction in } \\
\text { cirrhotic patients with ascites }\end{array}$ & 61.4 & $\begin{array}{l}20 \% \text { albumin versus saline starting } \\
3 \text { hours after paracentesis }\end{array}$ & $\begin{array}{l}\text { Greater than } 100 \% \text { SCr increase to greater than } 2 \\
\mathrm{mg} / \mathrm{dL}\end{array}$ \\
\hline $\begin{array}{l}\text { Brunkhorst et } \\
\text { al. [25], } 2008\end{array}$ & Severe sepsis or septic shock & 64.7 & $\begin{array}{l}10 \% \text { pentastarch versus Ringer's } \\
\text { lactate }\end{array}$ & Need for renal replacement therapy ${ }^{a}$ \\
\hline $\begin{array}{l}\text { Mclntyre et } \\
\text { al. [26], } 2008\end{array}$ & Early septic shock & 63.3 & $\begin{array}{l}10 \% \text { pentastarch versus normal } \\
\text { saline }\end{array}$ & Requirement for dialysis during hospitalization \\
\hline $\begin{array}{l}\text { Chen et al. } \\
\text { [27], } 2009\end{array}$ & Spontaneous bacterial peritonitis & 56.5 & $\begin{array}{l}\text { Cephalosporins with versus } \\
\text { without } 50 \mathrm{~mL} 20 \% \text { albumin on } \\
\text { days } 1 \text { to } 3\end{array}$ & $\begin{array}{l}\text { Greater than } 50 \% \mathrm{SCr} \text { increase and, in patients } \\
\text { without pre-existing renal failure, greater than } 1.5 \\
\mathrm{mg} / \mathrm{dL} \mathrm{SCr}\end{array}$ \\
\hline
\end{tabular}

${ }^{a}$ Need based on the presence of acute renal failure or another indication such as volume overload or hyperkalemia. Acute renal failure, defined as a doubling of the baseline serum creatinine ( $\mathrm{SCr}$ ) level or the need for renal replacement therapy, was evaluated as an additional separate endpoint in this trial. For the metaanalysis, only the data for renal replacement therapy were used. AKI, acute kidney injury; BUN, blood urea nitrogen; CPB, cardiopulmonary bypass; HES, hydroxyethyl starch; ICU, intensive care unit.

\section{Mortality}

Among all 11 included trials, 283 of 1,220 patients (23\%) died. At least one death occurred in 10 of the 11 included trials, allowing those 10 trials (with a total of 1,185 patients) to be included in a meta-analysis evaluating the OR for mortality (Figure 3 ). The only trial with no deaths assessed hyperoncotic albumin in the treatment of ascites [20]. Hyperoncotic albumin reduced the odds of mortality by $48 \%$ (OR 0.52 , CI 0.28 to $0.95 ; P=0.035$; Figure 3$)$. No significant heterogeneity $\left(P=0.81 ; \mathrm{I}^{2}=0 \%\right)$ or publication $(P=0.12)$ bias was present regarding mortality in the six trials of hyperoncotic albumin with at least one death. Conversely, hyperoncotic HES raised the odds of mortality by $41 \%$ (OR 1.41 , CI 1.01 to $1.96 ; P=0.043$ ). The mortality data in the hyperoncotic HES trials did not display either heterogeneity $\left(P=0.89 ; \mathrm{I}^{2}=0 \%\right)$ or publication $(P=0.14)$ bias.

\section{Discussion}

This meta-analysis of RCTs did not support the hypothesis that hyperoncotic colloids per se are injurious to the kidney. It appeared that, within physiologic ranges, the specific properties of the colloid molecule rather than concentration are the major determinants of renal effects. According to our results, administration of hyperoncotic albumin was associated with reduced risk of AKI as well as with improved survival. By contrast, HES displayed nephrotoxicity and worsened survival.

Certain limitations of this meta-analysis should be noted. Criteria for diagnosing AKI were not standardized. Other than one surgery trial, all six other included trials of hyperoncotic albumin involved cirrhotic patients, whereas those evaluating hyperoncotic HES all concerned surgery or sepsis. Thus, the clinical settings for evaluation of the two hyperoncotic colloids were largely non-overlapping. 


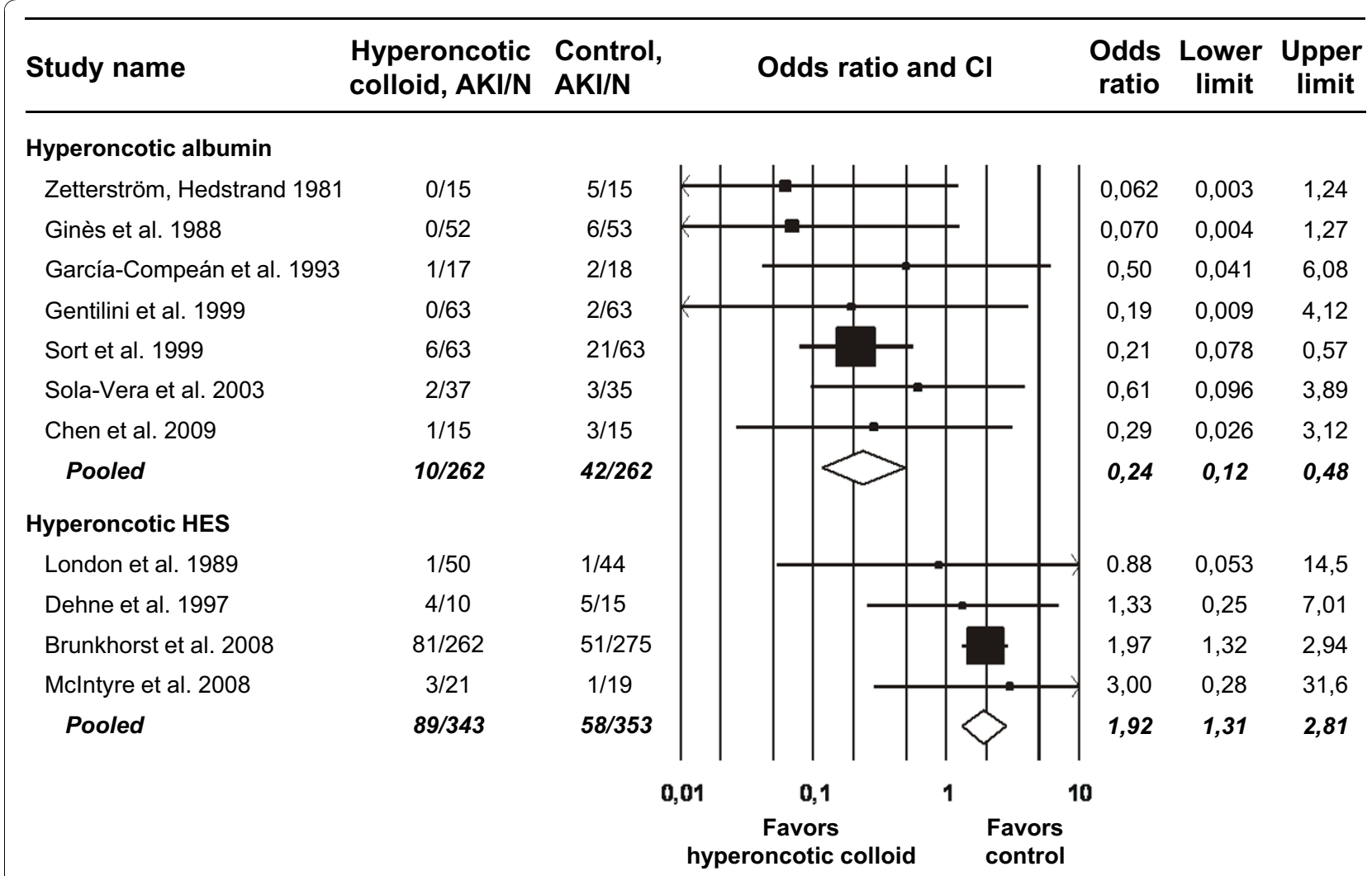

Figure 2 Meta-analysis of acute kidney injury (AKI) after hyperoncotic colloid administration. Data points are scaled in proportion to meta-analytic weight. Error bars indicate confidence interval (Cl). HES, hydroxyethyl starch; N, total number of patients.

Six of the seven included trials evaluating hyperoncotic albumin involved cirrhotic patients. In all six of those trials, the observed reduction in the AKI incidence was less than in the seventh trial, which evaluated major abdominal surgery patients [17]. Extravascular fluid accumulation is a common complication of cirrhosis, which might be precipitated or exacerbated by hypo-oncotic fluid, and in five of the six included trials of cirrhotic patients, the selected control regimen consisted of no volume expander. The possibility could be entertained that volume expansion with a control fluid might have produced the same results as did hyperoncotic albumin in those trials. In one included trial [24], however, cirrhotic patients with ascites did receive saline as the control fluid. That group developed paracentesis-induced circulatory dysfunction with a frequency that was significantly higher $(33.3 \%)$ than that of the patients allocated to hyperoncotic albumin (11.4\%). Additionally, a randomized trial not included in this meta-analysis compared hyperoncotic $20 \%$ albumin with iso-oncotic 6\% HES 200/0.5 in cirrhotic patients with spontaneous bacterial peritonitis [28]. Although the trial was not powered to assess AKI, the incidence of AKI was nevertheless lower in the hyperoncotic albumin group (OR 0.29 , CI 0.03 to 3.12), and significant improvement in circulatory function was demonstrated in that group but not among the patients assigned to iso-oncotic HES.

The present meta-analysis is the first to investigate AKI specifically after infusion of hyperoncotic 10\% HES. Prior systematic reviews and meta-analyses have not differentiated between iso-oncotic and hyperoncotic HES solutions [1-3,29]. Even in the CRYCO analysis, the designated hyperoncotic HES group did not actually receive hyperoncotic solutions exclusively [5]. Iso-oncotic 6\% HES 130/0.4, for example, was among the solutions assigned to the CRYCO hyperoncotic HES group.

In three of the four included trials evaluating hyperoncotic HES, AKI was more frequent in the hyperoncotic HES group than the control group, and in all four of those trials, mortality was higher in hyperoncotic HES recipients. Nevertheless, the preponderance of the statistical power was derived from a single large trial [25], and it should be recognized that the conclusions of the meta-analysis regarding hyperoncotic HES rest primarily on that trial. If that trial were to be excluded, the point estimates of the pooled ORs for AKI (1.53) and mortality (1.91) would be comparable to those without the 


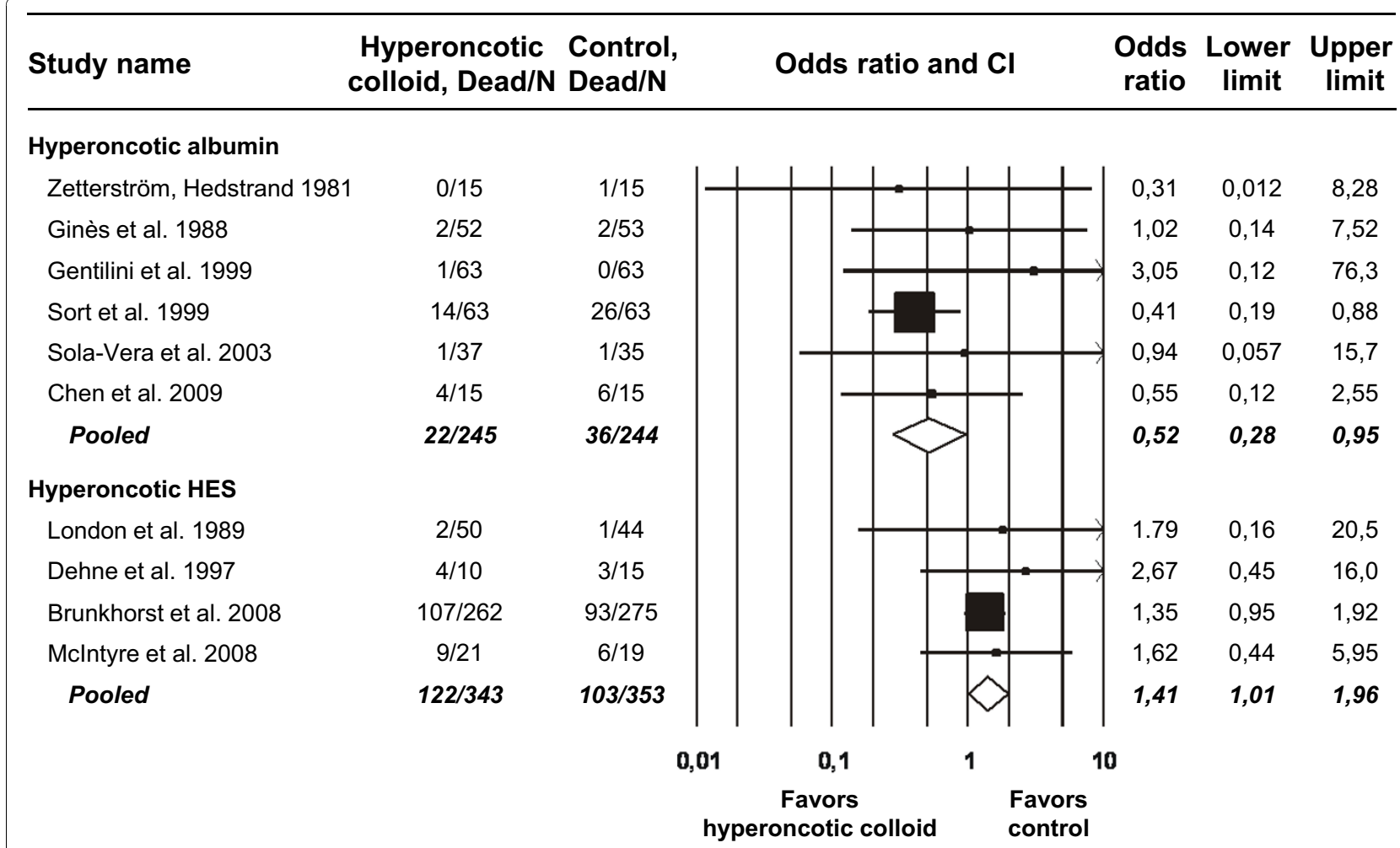

Figure 3 Meta-analysis of mortality after hyperoncotic colloid administration. Graphic conventions are the same as in Figure 2. $\mathrm{Cl}$, confidence interval; HES, hydroxyethyl starch; N, total number of patients.

exclusion (1.92 and 1.41, respectively); however, the effects would no longer be statistically significant.

While this meta-analysis has shown increased risk of AKI because of hyperoncotic HES, randomized trials have demonstrated similar deleterious renal effects in patients receiving iso-oncotic HES $[15,16]$. Furthermore, in the CRYCO analysis, the incidence of AKI among recipients of iso-oncotic $6 \%$ HES $130 / 0.4$ was similar to that of recipients of other evaluated HES solutions.

The present finding of renal protection attributable to hyperoncotic albumin in randomized trials is in contrast to the report of increased AKI in the hyperoncotic albumin group from the CRYCO analysis. Several factors may limit the reliability and generalizability of the CRYCO results with respect to hyperoncotic albumin, namely use of hyperoncotic albumin in a small minority of the most severely ill patients, concomitant infusion of other colloids, absence of a demonstrated dose-response relationship, and exclusion of cirrhotic patients.

No evidence of adverse renal effects was uncovered in a multicenter study of 600 patients receiving $25 \%$ albumin [14]. In that observational study, which was specifically designed to evaluate safety, normothermic hypoproteinemic patients at 14 US hospitals received multiple infusions of 80 to $100 \mathrm{~mL}$ of $25 \%$ albumin over a maximum period of 570 days. Forty-four patients underwent more than 10 infusions each, and the cumulative dose administered to five patients exceeded $800 \mathrm{~g}$. The patients were closely monitored for adverse events, including pyrogenic reactions, anaphylactoid and cardiovascular symptoms, and pulmonary edema. Post-mortem examination of 16 patients who had received $25 \%$ albumin doses up to $813 \mathrm{~g}$ each showed no evidence of abnormal albumin storage or other renal abnormalities that could not be explained by the disease of which the patients died.

On the basis of the CRYCO findings, recently issued clinical guidelines recommended the avoidance of hyperoncotic dextran, HES, and albumin solutions because of the risk for renal dysfunction [30]. In light of this meta-analysis and the limitations of the CRYCO study, such a blanket recommendation would appear to be unwarranted. A more differentiated approach to the use of these solutions is needed, as recommended in a recent publication [4].

Albumin-mediated renoprotection may be explained by several mechanisms, including maintaining renal perfusion $[6,31,32]$, promoting proximal tubular integrity and function [22,33-38], binding of endogenous toxins and nephrotoxic drugs [39-42], and preventing oxidative 
damage and binding and delivering protective lysophosphatidic acid $[34,36,43,44]$. The important renoprotective role of serum albumin was underscored by a recent meta-analysis showing hypoalbuminemia to be a potent independent risk factor both for AKI and for death following the development of AKI [45].

Many medications have been associated with toxic effects on the kidney [46]. Because the kidney receives a quarter of resting cardiac output, glomerular, tubular, and renal interstitial cells can be exposed to substantial concentrations of medications and their metabolites, which can induce changes in kidney structure and function. On the other hand, several mechanisms of HESinduced AKI are reported. HES is degraded and its degradation products are reabsorbed mainly in the proximal tubule. Intracellular accumulation resulting in vacuolization of the proximal tubule may result in functional impairment. Post-mortem examination of 12 patients who received repeated HES 200/0.5 infusions and died after protracted RRT because of ARF showed that the kidney contained the highest tissue concentration of HES compared with any of the other six major organs evaluated [47]. Degradation products of HES are cleared primarily via the kidney. Some of these breakdown products are excreted in the urine, but others can be taken up by the cells of the proximal tubule through pinocytosis. The pinocytotic vacuoles subsequently fuse with each other and lysosomes to form larger vacuoles, which can displace other cellular components. HES can accumulate through storage in these oversized lysosomes. There have been no studies published thus far on the type of HES metabolites taken up in the vacuoles and the ability of lysosomal enzymes to degrade them. Vacuolization and swelling of the renal proximal tubular cells are often harbingers of AKI [48].

The histopathologic pattern of acute tubular injury typical of HES accumulation in the kidney is osmotic nephrosis. This phenomenon was first described in 1940 when patients with increased intracranial pressure were treated with intravenous sucrose solutions [48]. Dextran, another colloid composed of glucose units, has also been associated with osmotic nephrosis [1], as have maltose and mannitol [48]. Numerous case reports have documented osmotic nephrosis in patients developing AKI after HES exposure [49-52]. In a randomized trial, HES increased the need for RRT after kidney transplantation, and all biopsied patients receiving HES showed osmotic nephrosis, but none in the control group did [16]. Hydroxyethylation of constituent glucose molecules in the synthesis of HES is specifically intended to retard degradation and prolong action. Osmotic nephrosis resulting from HES exposure can be extremely long-lasting, if not permanent. During long-term follow-up after orthotopic liver transplantation, osmotic nephrosis attributable to HES persisted up to 10 years in $61 \%$ of patients [53].

Decreasing levels of renoprotective albumin might be an additional mechanism underlying the nephrotoxicity of HES, which has been shown to cause iatrogenic hypoalbuminemia [54-59]. Inflammatory processes may also contribute to HES-mediated AKI [60]. Further research is needed on pathophysiologic mechanisms as well as on the metabolic fate of HES in the kidney.

Only relatively recently has attention been focused on the possibility that hyperoncotic fluids per se might be injurious to the kidney. Accordingly, the hypotheses tested in the trials of this meta-analysis were not formulated specifically in terms of evaluating a hyperoncotic colloid. Nevertheless, in those trials, patients were randomly allocated to a hyperoncotic colloid or control regimen, and the trials therefore do provide relevant evidence of the renal effects of hyperoncotic colloids. It has recently become increasingly common to discuss 'hyperoncotic acute renal failure'. This meta-analysis raises doubt that such a concept can satisfactorily account for AKI in patients receiving colloids.

\section{Conclusions}

Currently available randomized trial evidence suggests that hyperoncotic albumin solutions may reduce the incidence of AKI and death. The opposite effects appear to be exerted by hyperoncotic HES.

\section{Key messages}

- It has been hypothesized that hyperoncotic colloid solutions may damage the kidney. A meta-analysis of randomized controlled trials was performed to test this hypothesis.

- Hyperoncotic albumin decreased the odds of acute kidney injury by $76 \%$ and of death by $48 \%$.

- Hyperoncotic hydroxyethyl starch increased the odds of acute kidney injury by $92 \%$ and of death by $41 \%$.

- Hyperoncotic colloids per se do not appear to be harmful to the kidney.

- Renal effects may be specific to the particular colloid molecule.

\section{Abbreviations}

AKI: acute kidney injury; ARF: acute renal failure; $\mathrm{Cl}$ : confidence interval; COP. colloid osmotic pressure; CRYCO: CRYstalloids or Colloids; HES: hydroxyethyl starch; IQR: interquartile range; OR: odds ratio; RCT: randomized controlled trial; RRT: renal replacement therapy.

\section{Acknowledgements}

The authors wish to thank Rajam Csordas-lyer for critical reading of the manuscript.

\section{Author details}

'Department of Internal Medicine, Central Hospital of Bolzano, Lorenz Böhler Street 5, 39100 Bolzano, Italy. ${ }^{2}$ Department of Internal Medicine I, Medical 
University of Innsbruck, Anichstrasse 35, 6020 Innsbruck, Austria. ${ }^{3}$ Department of Vascular and Thoracic Surgery, Central Hospital of Bolzano, Lorenz Böhler Street 5, 39100 Bolzano, Italy.

\section{Authors' contributions}

CJW conceived the meta-analysis and participated in its design and coordination, extracted data, performed statistical analysis, contributed to the interpretation of results, and helped to draft the manuscript. MJ participated in the design and coordination of the meta-analysis, contributed to the interpretation of results, and helped to draft the manuscript. All authors participated in searching for trials and determining their eligibility for inclusion in the meta-analysis. All authors read and approved the final manuscript.

\section{Authors' information}

CJW and MJ were co-authors of a recent meta-analysis on hypoalbuminemia and acute kidney injury. CJW authored a systematic review on the use of hydroxyethyl starch for fluid management in sepsis. MJ first-authored the publication of an expert opinion statement of the European Society of Intensive Care Medicine Working Group for Nephrology on renal protection in the intensive care unit.

\section{Competing interests}

CJW has received speaker fees and travel reimbursements from manufacturers of plasma-derived therapies (CSL Behring, King of Prussia, PA, USA, and Kedrion, Prato, Italy). The other authors declare that they have no competing interests.

Received: 10 August 2010 Revised: 15 October 2010

Accepted: 28 October 2010 Published: 28 October 2010

\section{References}

1. Davidson IJ: Renal impact of fluid management with colloids: a comparative review. Eur J Anaesthesiol 2006, 23:721-738.

2. Dart AB, Mutter TC, Ruth CA, Taback SP: Hydroxyethyl starch (HES) versus other fluid therapies: effects on kidney function. Cochrane Database Syst Rev 2010, 1:CD007594.

3. Zarychanski $R$, Turgeon AF, Fergusson DA, Cook DJ, Hébert P, Bagshaw SM, Monsour D, McIntyre L: Renal outcomes and mortality following hydroxyethyl starch resuscitation of critically ill patients: systematic review and meta-analysis of randomized trials. Open Med 2009, 3:196-209.

4. Joannidis M, Druml W, Forni LG, Groeneveld AB, Honore P, Oudemans-van Straaten HM, Ronco C, Schetz MR, Woittiez AJ: Prevention of acute kidney injury and protection of renal function in the intensive care unit Expert opinion of the working group for nephrology, ESICM. Intensive Care Med 2010, 36:392-411.

5. Schortgen F, Girou E, Deye N, Brochard L: The risk associated with hyperoncotic colloids in patients with shock. Intensive Care Med 2008, 34:2157-2168.

6. Baylis C, Ichikawa I, Willis WT, Wilson CB, Brenner BM: Dynamics of glomerular ultrafiltration. IX. Effects of plasma protein concentration. Am J Physiol 1977, 232:F58-71.

7. Hiippala S, Linko K, Myllyla G, Lalla M, Makelainen A: Albumin, HES 120 and dextran 70 as adjuvants to red blood cell concentrates: a study on colloid osmotic pressure changes in vitro. Acta Anaesthesiol Scand 1991, 35:654-659.

8. Webb AR, Barclay SA, Bennett ED: In vitro colloid osmotic pressure of commonly used plasma expanders and substitutes: a study of the diffusibility of colloid molecules. Intensive Care Med 1989, 15:116-120.

9. Tønnessen T, Tølløfsrud S, Kongsgaard UE, Noddeland H: Colloid osmotic pressure of plasma replacement fluids. Acta Anaesthesiol Scand 1993, 37:424-426.

10. Hiippala S, Linko K, Myllyla G, Lalla M, Hekali R, Makelainen A: Replacement of major surgical blood loss by hypo-oncotic or conventional plasma substitutes. Acta Anaesthesiol Scand 1995, 39:228-235.

11. Nielsen VG, Baird MS, Brix AE, Matalon S: Extreme, progressive isovolemic hemodilution with $5 \%$ human albumin, PentaLyte, or Hextend does not cause hepatic ischemia or histologic injury in rabbits. Anesthesiology 1999, 90:1428-1435.

12. Cabrales $P$, Intaglietta $M$, Tsai AG: Increase plasma viscosity sustains microcirculation after resuscitation from hemorrhagic shock and continuous bleeding. Shock 2005, 23:549-555.
13. Jacob M, Chappell D, Conzen P, Wilkes MM, Becker BF, Rehm M: Smallvolume resuscitation with hyperoncotic albumin: a systematic review of randomized clinical trials. Crit Care 2008, 12:R34.

14. Janeway CA, Gibson ST, Woodruff LM, Heyl JT, Bailey OT, Newhouser LR: Chemical, clinical, and immunological studies on the products of human plasma fractionation. VII. Concentrated human serum albumin. J Clin Invest 1944, 23:465-490.

15. Schortgen F, Lacherade JC, Bruneel F, Cattaneo I, Hemery F, Lemaire F, Brochard $L$ : Effects of hydroxyethylstarch and gelatin on renal function in severe sepsis: a multicentre randomised study. Lancet 2001, 357:911-916.

16. Cittanova ML, Leblanc I, Legendre C, Mouquet C, Riou B, Coriat P: Effect of hydroxyethylstarch in brain-dead kidney donors on renal function in kidney-transplant recipients. Lancet 1996, 348:1620-1622.

17. Zetterström $H$, Hedstrand U: Albumin treatment following major surgery. I. Effects on plasma oncotic pressure, renal function and peripheral oedema. Acta Anaesthesiol Scand 1981, 25:125-132.

18. Ginès $P$, Titó $L$, Arroyo $V$, Planas $R$, Panés J, Viver J, Torres $M$, Humbert $P$, Rimola A, Llach J, Badalamenti S, Jiménez W, Gaya J, Rodés J: Randomized comparative study of therapeutic paracentesis with and without intravenous albumin in cirrhosis. Gastroenterology 1988, 94:1493-1502.

19. London MJ, Ho JS, Triedman JK, Verrier ED, Levin J, Merrick SH, Hanley FL, Browner WS, Mangano DT: A randomized clinical trial of $10 \%$ pentastarch (low molecular weight hydroxyethyl starch) versus 5\% albumin for plasma volume expansion after cardiac operations. J Thorac Cardiovasc Surg 1989, 97:785-797.

20. García-Compeán D, Villarreal JZ, Cuevas HB, Cantú DAG, Estrella M, Tamez EG, Castillo RV, Barragán RF: Total therapeutic paracentesis (TTP) with and without intravenous albumin in the treatment of cirrhotic tense ascites: a randomized controlled trial. Liver 1993, 13:233-238.

21. Dehne MG, Mühling J, Sablotzki A, Papke G, Kuntzsch U, Hempelmann G: Effect of hydroxyethyl starch solution on kidney function in surgical intensive care patients. Anasthesiol Intensivmed Notfallmed Schmerzther 1997, 32:348-354.

22. Gentilini P, Casini-Raggi V, Di Fiore G, Romanelli RG, Buzzelli G, Pinzani M, La Villa G, Laffi G: Albumin improves the response to diuretics in patients with cirrhosis and ascites: results of a randomized, controlled trial. J Hepatol 1999, 30:639-645

23. Sort $P$, Navasa $M$, Arroyo $V$, Aldeguer $X$, Planas R, Ruiz-del-Arbol $L$, Castells $L$, Vargas $V$, Soriano $G$, Guevara $M$, Ginès $P$, Rodés J: Effect of intravenous albumin on renal impairment and mortality in patients with cirrhosis and spontaneous bacterial peritonitis. N Engl J Med 1999, 341:403-409.

24. Sola-Vera J, Miñana J, Ricart E, Planella M, González B, Torras X, Rodríguez J, Such J, Pascual S, Soriano G, Pérez-Mateo M, Guarner C: Randomized trial comparing albumin and saline in the prevention of paracentesisinduced circulatory dysfunction in cirrhotic patients with ascites. Hepatology 2003, 37:1147-1153.

25. Brunkhorst FM, Engel C, Bloos F, Meier-Hellmann A, Ragaller M, Weiler N, Moerer O, Gruendling M, Oppert M, Grond S, Olthoff D, Jaschinski U, John S, Rossaint R, Welte T, Schaefer M, Kern P, Kuhnt E, Kiehntopf M, Hartog C, Natanson C, Loeffler M, Reinhart K: Intensive insulin therapy and pentastarch resuscitation in severe sepsis. N Engl J Med 2008, 358:125-139.

26. McIntyre LA, Fergusson D, Cook DJ, Rankin N, Dhingra V, Granton J, Magder S, Stiell I, Taljaard M, Hebert PC: Fluid resuscitation in the management of early septic shock (FINESS): a randomized controlled feasibility trial. Can J Anaesth 2008, 55:819-826.

27. Chen T-A, Tsao Y-C, Chen A, Lo G-H, Lin C-K, Yu H-C, Cheng L-C, Hsu P-I, Tsai W-L: Effect of intravenous albumin on endotoxin removal, cytokines, and nitric oxide production in patients with cirrhosis and spontaneous bacterial peritonitis. Scand J Gastroenterol 2009, 44:619-625.

28. Fernández J, Monteagudo J, Bargallo X, Jiménez W, Bosch J, Arroyo V, Navasa M: A randomized unblinded pilot study comparing albumin versus hydroxyethyl starch in spontaneous bacterial peritonitis. Hepatology 2005, 42:627-634.

29. Wiedermann CJ: Systematic review of randomized clinical trials on the use of hydroxyethyl starch for fluid management in sepsis. BMC Emerg Med 2008, 8:1-8.

30. Brochard L, Abroug F, Brenner M, Broccard AF, Danner RL, Ferrer M, Laghi F, Magder S, Papazian L, Pelosi P, Polderman KH: An Official ATS/ERS/ESICM/ SCCM/SRLF Statement: Prevention and Management of Acute Renal 
Failure in the ICU Patient: an international consensus conference in intensive care medicine. Am J Respir Crit Care Med 2010, 181:1128-1155.

31. Gerkens JF: Reproducible vasodilatation by platelet-activating factor in blood- and Krebs-perfused rat kidneys is albumin-dependent. Eur $J$ Pharmacol 1990, 177:119-126.

32. Kaufmann MA, Castelli I, Pargger H, Drop L: Nitric oxide dose-response study in the isolated perfused rat kidney after inhibition of endothelium-derived relaxing factor synthesis: the role of serum albumin. J Pharmacol Exp Ther 1995, 273:855-862.

33. Ott CE, Haas JA, Cuche JL, Knox FG: Effect of increased peritubule protein concentration on proximal tubule reabsorption in the presence and absence of extracellular volume expansion. J Clin Invest 1975, 55:612-620.

34. Levine JS, Koh JS, Triaca V, Lieberthal W: Lysophosphatidic acid: a novel growth and survival factor for renal proximal tubular cells. Am J Physiol 1997, 273:F575-585.

35. Dixon R, Brunskill NJ: Activation of mitogenic pathways by albumin in kidney proximal tubule epithelial cells: implications for the pathophysiology of proteinuric states. J Am Soc Nephrol 1999, 10:1487-1497.

36. Iglesias J, Abernethy VE, Wang Z, Lieberthal W, Koh JS, Levine JS: Albumin is a major serum survival factor for renal tubular cells and macrophages through scavenging of ROS. Am J Physiol 1999, 277:F711-722.

37. Romanelli RG, La Villa G, Barletta G, Vizzutti F, Lanini F, Arena U, Boddi V, Tarquini R, Pantaleo P, Gentilini P, Laffi G: Long-term albumin infusion improves survival in patients with cirrhosis and ascites: an unblinded randomized trial. World J Gastroenterol 2006, 12:1403-1407.

38. Lee YJ, Han HJ: Albumin-stimulated DNA synthesis is mediated by $\mathrm{Ca}^{2}$ +/PKC as well as EGF receptor-dependent p44/42 MAPK and NF-KB signal pathways in renal proximal tubule cells. Am J Physiol Renal Physiol 2008, 294:F534-541

39. Contreras AM, Ramírez M, Cueva L, Alvarez S, de Loza R, Gamba G: Low serum albumin and the increased risk of amikacin nephrotoxicity. Rev Invest Clin 1994, 46:37-43.

40. Pockaj BA, Yang JC, Lotze MT, Lange JR, Spencer WF, Steinberg SM, Topalian SL, Schwartzentruber DJ, White DE, Rosenberg SA: A prospective randomized trial evaluating colloid versus crystalloid resuscitation in the treatment of the vascular leak syndrome associated with interleukin-2 therapy. J Immunother Emphasis Tumor Immunol 1994, 15:22-28.

41. Mitzner SR, Stange J, Klammt S, Risler T, Erley CM, Bader BD, Berger ED, Lauchart W, Peszynski P, Freytag J, Hickstein H, Loock J, Löhr J-M, Liebe S, Emmrich J, Korten G, Schmidt R: Improvement of hepatorenal syndrome with extracorporeal albumin dialysis MARS: results of a prospective, randomized, controlled clinical trial. Liver Transpl 2000, 6:277-286.

42. Wratten ML, Sereni L, Tetta C: Oxidation of albumin is enhanced in the presence of uremic toxins. Ren Fail 2001, 23:563-571.

43. Stocker R, Glazer AN, Ames BN: Antioxidant activity of albumin-bound bilirubin. Proc Natl Acad Sci USA 1987, 84:5918-5922.

44. Quinlan GJ, Mumby S, Martin GS, Bernard GR, Gutteridge JM, Evans TW: Albumin influences total plasma antioxidant capacity favorably in patients with acute lung injury. Crit Care Med 2004, 32:755-759.

45. Wiedermann CJ, Wiedermann W, Joannidis M: Hypoalbuminemia and acute kidney injury: a meta-analysis of observational clinical studies. Intensive Care Med 2010, 36:1657-1665.

46. Choudhury D, Ahmed Z: Drug-associated renal dysfunction and injury. Nat Clin Pract Nephrol 2006, 2:80-91.

47. Lukasewitz $\mathrm{P}$, Kroh U, Löwenstein $\mathrm{O}$, Krämer M, Lennartz H: Quantitative investigations of tissue accumulation of intermediate molecular weight hydroxyethyl starch in patients with multiple organ failure. J Anaesth Intensivbeh 1998, 3:42-46.

48. Dickenmann M, Oettl T, Mihatsch MJ: Osmotic nephrosis: acute kidney injury with accumulation of proximal tubular lysosomes due to administration of exogenous solutes. Am J Kidney Dis 2008, 51:491-503.

49. de Labarthe A, Jacobs F, Blot F, Glotz D: Acute renal failure secondary to hydroxyethylstarch administration in a surgical patient. Am J Med 2001, 111:417-418.

50. Peron S, Mouthon L, Guettier C, Brechignac S, Cohen P, Guillevin L: Hydroxyethyl starch-induced renal insufficiency after plasma exchange in a patient with polymyositis and liver cirrhosis. Clin Nephrol 2001, 55:408-411.
51. Ebcioglu Z, Cohen DJ, Crew RJ, Hardy MA, Ratner LE, D'Agati VD, Markowitz GS: Osmotic nephrosis in a renal transplant recipient. Kidney Int 2006, 70:1873-1876

52. Hagne C, Schwarz A, Gaspert A, Giambarba C, Keusch G: HAES in septic shock - sword of Damocles? Schweiz Med Forum 2009, 9:304-306

53. Pillebout E, Nochy D, Hill G, Conti F, Antoine C, Calmus Y, Glotz D: Renal histopathological lesions after orthotopic liver transplantation (OLT). Am $J$ Transplant 2005, 5:1120-1129.

54. Lamke LO, Liljedahl SO: Plasma volume changes after infusion of various plasma expanders. Resuscitation 1976, 5:93-102.

55. Nagy KK, Davis J, Duda J, Fildes J, Roberts R, Barrett J: A comparison of pentastarch and lactated Ringer's solution in the resuscitation of patients with hemorrhagic shock. Circ Shock 1993, 40:289-294.

56. Degrémont $A C$, Ismail $M$, Arthaud $M$, Oulare $B$, Mundler $O$, Paris $M$, Baron JF: Mechanisms of postoperative prolonged plasma volume expansion with low molecular weight hydroxethyl starch (HES 200/0.62, 6\%). Intensive Care Med 1995, 21:577-583.

57. Rock G, Sutton DM, Freedman J, Nair RC: Pentastarch instead of albumin as replacement fluid for therapeutic plasma exchange. The Canadian Apheresis Group. J Clin Apheresis 1997, 12:165-169.

58. Goss GA, Weinstein R: Pentastarch as partial replacement fluid for therapeutic plasma exchange: effect on plasma proteins, adverse events during treatment, and serum ionized calcium. J Clin Apheresis 1999, 14:114-121.

59. Boldt J, Brosch C, Röhm K, Lehmann A, Mengistu A, Suttner S: Is albumin administration in hypoalbuminemic elderly cardiac surgery patients of benefit with regard to inflammation, endothelial activation, and longterm kidney function? Anesth Analg 2008, 107:1496-1503.

60. Hüter L, Simon TP, Weinmann L, Schuerholz T, Reinhart K, Wolf G, Amann KU, Marx G: Hydroxyethylstarch impairs renal function and induces interstitial proliferation, macrophage infiltration and tubular damage in an isolated renal perfusion model. Crit Care 2009, 13:R23.

\section{doi:10.1186/cc9308}

Cite this article as: Wiedermann et al:: Hyperoncotic colloids and acute kidney injury: a meta-analysis of randomized trials. Critical Care 2010 14: R191.

\section{Submit your next manuscript to BioMed Central and take full advantage of:}

- Convenient online submission

- Thorough peer review

- No space constraints or color figure charges

- Immediate publication on acceptance

- Inclusion in PubMed, CAS, Scopus and Google Scholar

- Research which is freely available for redistribution 